\title{
Effect of the plantation age on the use of Eucalyptus stands by medium to large-sized wild mammals in south-eastern Brazil
}

\author{
Thiago PC Timo ${ }^{(1)}$, Maria Carolina Lyra-Jorge ${ }^{(2)}$, Carla Gheler-Costa ${ }^{(3)}$, \\ Luciano M Verdade ${ }^{(4)}$
}

In the São Paulo State (south-eastern Brazil), Eucalyptus plantations have been replacing large areas formerly occupied by pastures used for livestock production. Such land use change may affect the habitat use by wildlife in these anthropic landscapes. In this region, the commercial Eucalyptus plantations for paper and cellulose production usually take from 6 to 7 years to be harvested. During its production cycle, Eucalyptus stands vary from an open savanna-like environment just after plantation, when plants still resemble bushes, to a forest-like environment with densely distributed 18-meter tall trees. Previous studies show that Eucalyptus plantations in south-eastern Brazil are used by generalist species, including medium and large sized mammals. However, the possible influence of such dramatic temporal environmental heterogeneity on the wildlife habitat use in Eucalyptus plantations is still unknown. In this study, we assess the influence of the Eucalyptus stand age on the local patterns of distribution and abundance of middle to large-sized wild mammals. Our results show an increase not only in species richness, but also in frequency of occurrences along the commercial cycle of the Eucalyptus plantations, with a steep decline in both habitats just before harvest. Such pattern may be related to weed control practices which significantly reduce the understory vegetation, particularly at the end of the commercial cycle while preparing for harvesting. Future studies should prioritize the possible variation of the trophic structure in Eucalyptus plantations along commercial cycles as a response of wildlife-friendly silvicultural/agricultural management practices.

Keywords: Forestry, Silvicultural Landscapes, Anthropic Environments, Wildlife, Temporal Heterogeneity

\begin{abstract}
Introduction
Patterns of wildlife distribution and abundance have suffered alterations worldwide due to human occupation and related activities (Tilman et al. 2001). The agriculture expansion has replaced the original vegetation and fragmented primary environments, thus affecting wildlife patterns of habitat use (Goodwin \& Fahrig 2002, Fahrig 2003). However, studies in agricultural landscapes have shown the use of man-made habitats by
\end{abstract}

B-diversity (Moffett 2000, Parker \& Brown 2000 ). In an agricultural landscape, a considerable loss of biodiversity occurs where monocultures are spatially more homogenous. However, the environment of Eucalyptus plantations varies dramatically along their commercial cycle. At the first stage, it assumes a bushy structure that later evolves into a forest, which is totally clear-cut at the end of 6-7 years (Turnbull 1995, Wagner et al. 2006). Therefore, these artificial forests present great temporal heterogeneity which may affect patterns of abundance and distribution of resident wildlife, not only for small mammals (Martin et al. 2012), but also for their predators (Verdade et al. 2011). In fact, recent studies show these forests are capable of maintaining a resident wildlife (Penteado 2006, Lyra-Jorge et al. 2008, Dotta \& Verdade 2011, Martin et al. 2012). This study aims at assessing the temporal variation of the specific composition and relative abundance of middle to large-sized mammal species found in Eucalyptus plantations in the State of São Paulo, Southeastern Brazil.

Eucalyptus plantations currently occupy over one million hectares in São Paulo, the richest and most developed state in Brazil. Their main commodities are the pulp and paper (ABRAF 2013). Together with livestock production, the ethanol agroindustry primarily based on sugarcane and the pulp and paper silvicultural industry primarily based on Eucalyptus are the main agroindustrial sectors of São Paulo state. However, unlike the other two agroindustrial sectors, pulp and paper industries follow Brazilian environmental laws relatively well, due to market pressure posed by certification organizations such as the Forest Stewardship Council (FSC - Verdade et al. 2012). Accordingly, the assessment of the distribution of middle to large-sized mammals in Eucalyptus plantations may give significant advances to both the environmental certification process of this sector and the elaboration of public policies which can result in the inclusion of such landscapes in the context of wildlife conservation.

\section{Materials and Methods}

\section{Study Area}

This study was conducted at three Eucalyptus commercial plantations located between Barra Bonita and Jurumirim reservoirs, Paranapanema River Basin, State of São Paulo, Southeastern Brazil (Fig. 1). The native vegetation cover in the region was composed of "Cerradão" (forested savannah) and semidecidual Atlantic forest (Veloso 1992). The climate is tropical (Köppen) with rainy summers and dry winters with average temperatures between 19.7 and $21.5^{\circ} \mathrm{C}$ (CEPAGRI-UNICAMP 2012). 


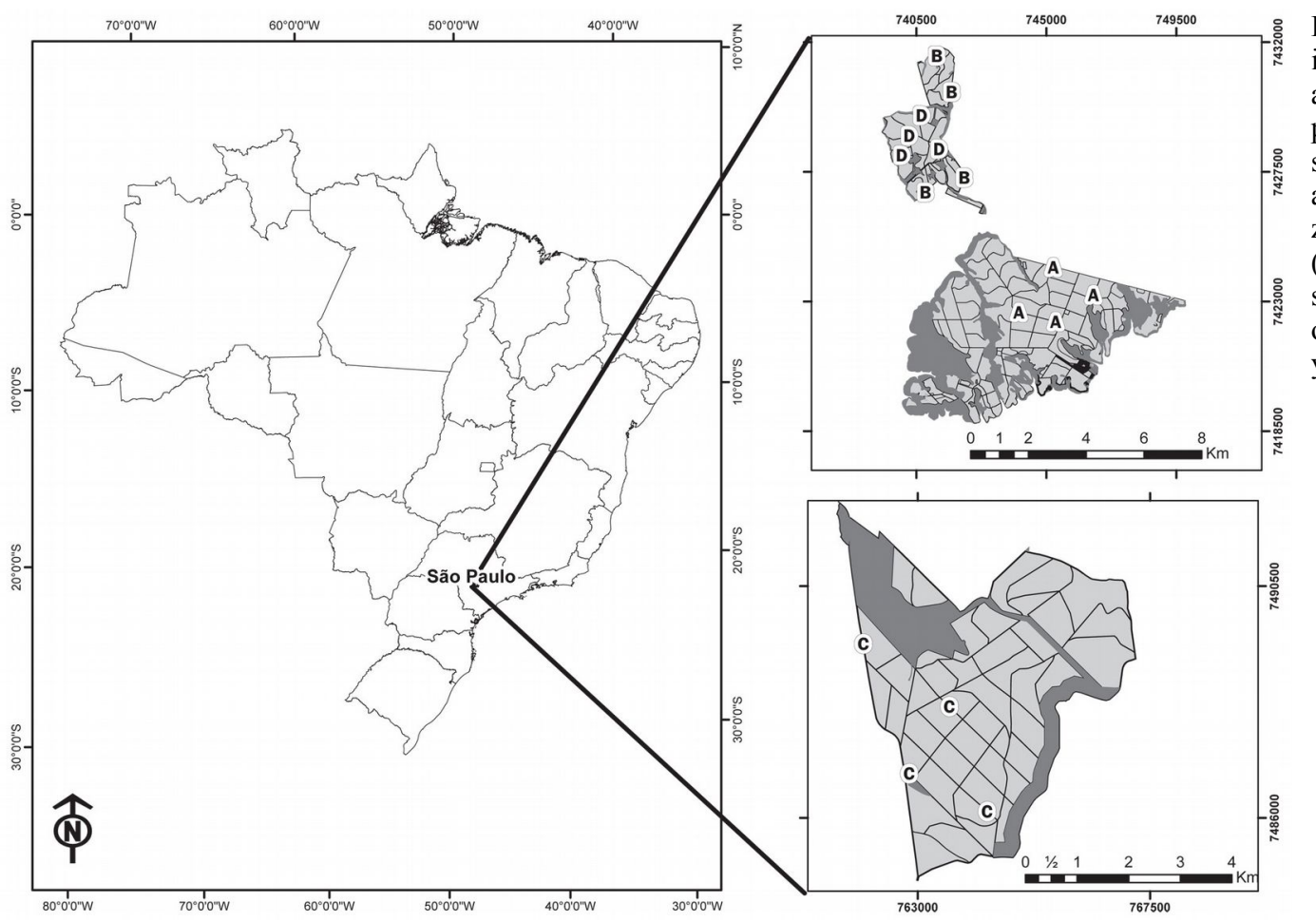

Fig. 1 - Location of study sites in Brazil and São Paulo State and the distribution of sampling sites on Eucalyptus stands in the plantation farms assessed in this study. (A): zero to one year old stands; (B): two to three year old stands; (C): four to five year old stands; (D): six to seven year old eucalypt stands.

The historical use of these lands dates back to the $18^{\text {th }}$ century with the deforestation for pasture establishment. In the late $19^{\text {th }}$ century, coffee plantations dominated the region, being replaced by sugarcane in the early $20^{\text {th }}$ century. At the end of the $20^{\text {th }}$ century, sugarcane began to be gradually replaced by Eucalyptus plantations, which currently covers approximately $40 \%$ of the Alto Paranapanema river basin, with only about $10 \%$ of remaining native vegetation left (Kronka et al. 2002).

\section{Sampling methodology}

The sampling period of this study was from August 2007 to February 2008, including seven two-day campaigns carried out every month. Sand plot for track counts (Wemmer et al. 1996, Pardini et al. 2003, Ray \& Zielinski 2008) and camera-traps (Karanth et al. 2004, Kays \& Slauson 2008) were used to detect middle to large-sized mammals. Sand plots were cleaned and camera-traps activated on the first day of the campaign, and data collection took place on the second day. The study area was divided into four age ranges of Eucalyptus stands: (i) 0-1 year; (ii) 2-3 years; (iii) 4-5 years; and (iv) 6-7 years (Fig. $1)$.

The surveys within sand plots took place using trails which were naturally formed by the space between the Eucalyptus tree rows, starting at the gravel roads that divided the stands. Sand plots were placed every $25 \mathrm{me}-$ ters along each trail, summing up ten sand plots per trail. Four trails were established for each Eucalyptus stand age range. Each trail was considered as a sample unit, totaling 16 sample units. The trails where the sand plots were placed received one cameratrap each, placed 75 meters from the trail entrance. The minimal distance between sampling units was one kilometer. As we considered frequency of occurrence as the dependent variable, independently of the actual species abundances, we could consider the sampling units as independent.

\section{Analytical methodology}

Mammals registered in the field surveys were grouped in the following trophic cate-

Tab. 1 - Detected mammal species, their taxonomy, trophic categories and numbers of occurrences by eucalypt stand-age range.

\begin{tabular}{|c|c|c|c|c|c|c|c|}
\hline \multirow{2}{*}{ Order } & \multirow{2}{*}{ Family } & \multirow{2}{*}{ Species } & \multirow{2}{*}{$\begin{array}{l}\text { Trophic } \\
\text { categories }\end{array}$} & \multicolumn{4}{|c|}{ Stand Age Range (years) } \\
\hline & & & & 0-1 & $2-3$ & 4-5 & 6-7 \\
\hline \multirow[t]{2}{*}{ Cingulata } & Dasypodidae & Dasypus novemcinctus (Linnaeus, 1758) & Omnivore & 1 & 2 & 8 & 1 \\
\hline & & Euphractus sexcinctus (Linnaeus, 1758) & Insectivore & 0 & 0 & 2 & 0 \\
\hline Pilosa & Myrmecophagidae & Myrmecophaga tridactyla (Linnaeus, 1758) & Insectivore & 2 & 5 & 2 & 1 \\
\hline \multirow[t]{2}{*}{ Lagomorpha } & Leporidae & Lepus sp. (Linnaeus, 1758) & Herbivore & 7 & 0 & 1 & 0 \\
\hline & & Sylvilagus brasiliensis (Linnaeus, 1758) & Herbivore & 0 & 1 & 0 & 0 \\
\hline \multirow[t]{3}{*}{ Artiodactyla } & Tayassuidae & Pecari tajacu (Linnaeus, 1758) & Herbivore & 1 & 0 & 0 & 0 \\
\hline & Cervidae & Mazama sp. (Rafinesque, 1817) & Herbivore & 1 & 3 & 4 & 0 \\
\hline & Bovidae & Bos taurus (Linnaeus, 1766) & Herbivore & 0 & 1 & 0 & 1 \\
\hline \multirow[t]{7}{*}{ Carnivora } & Felidae & Leopardus tigrinus (Shreber, 1775) & Carnivore & 1 & 0 & 0 & 0 \\
\hline & & Puma concolor (Linnaeus, 1771) & Carnivore & 0 & 0 & 2 & 0 \\
\hline & Canidae & Canis lupus (=familiaris) (Linnaeus, 1758) & Omnivore & 1 & 7 & 0 & 0 \\
\hline & & Cerdocyon thous (Linnaeus, 1766) & Omnivore & 5 & 4 & 6 & 0 \\
\hline & & Chrysocyon brachyurus (Illiger, 1815) & Omnivore & 5 & 8 & 9 & 0 \\
\hline & Mustelidae & Eira barbara (Linnaeus, 1758) & Omnivore & 0 & 0 & 1 & 0 \\
\hline & Procionidae & Nasua nasua (Linnaeus, 1766) & Omnivore & 0 & 0 & 1 & 0 \\
\hline
\end{tabular}


gories (adapted from Robinson \& Redford 1986a, 1986b, Fonseca et al. 1996, Dotta 2005, Dotta \& Verdade 2007): (a) carnivores; (b) herbivores; (c) omnivores and (d) insectivores. A list of detected species and their frequency of occurrence have been determined (taxonomic classification followed Wilson \& Reeder 2005). Sampling sufficiency was assessed by species incidence curves, with 100 randomizations in a rarefaction procedure (Sobs) by the Mao Tao method (Colwell et al. 2004). Specific richness was estimated by the Bootstrap method (Smith \& van Belle 1984). Species incidence curves were adjusted according to the Pearl-Reed trend model (Farnum \& Stanton 1989).

Data was tested for normality and homoscedasticity by Kolmogorov-Smirnoff test (Lilliefors 1967) and Levene's test (Levene 1960), respectively. Eucalyptus stand age ranges were mutually compared regarding species richness and frequency of occurrence for all species, and by trophic categories by Analysis of Variance (ANOVA - Hector et al. 2010) and Analysis of Means (ANOM Ott 1967). Venn diagrams (Moktefi \& Shin 2012) were used for the detection of overlaps among distinct stand ages regarding the species and trophic categories.

\section{Results}

A total of 15 species of middle to largesized mammals of 10 families was detected, including the following exotic species: cattle (Bos taurus), domestic dog (Canis lupus (= familiaris)) and the European hare (Lepus spp. - Tab. 1). This represents $86 \%$ of the total estimated species richness by Bootstrap, varying from $75.9 \%$ in 6-7 years-old stands to $90.6 \%$ in $2-3$ years-old stands (Tab. 2). The following trophic categories have been detected: herbivores, carnivores, omnivores and insectivores. Their detected and estimated species richness varied from $71.5 \%$ (insectivores in 0-1 and 6-7 years-old and carnivores in $0-1$ year-old stands) to $95.2 \%$ (omnivores in 2-3 years-old stands - Tab. 2).

Data set was homoscedastic and normally distributed $(\mathrm{p}<0.05)$. There was a significant variation in total species richness $(\mathrm{F}=6.81, \mathrm{df}=3, \mathrm{p}=0.006)$ and frequency occurrences $(\mathrm{F}=7.07, \mathrm{df}=3, \mathrm{p}=0.005)$, in relation to plantation age. However, such variation has only been detected in omnivores $(\mathrm{F}=9.33, \quad \mathrm{df}=3, \quad \mathrm{p}=0.002 ; \quad \mathrm{F}=9.95, \quad \mathrm{df}=3$, $\mathrm{p}=0.001)$, respectively, for species richness and frequency of occurrence (Fig. 2).

Seven species occurred exclusively at a single stand age: Leopardus tigrinus and Pecari tajacu at 0-1 year-old; Sylvilagus brasiliensis at 2-3 year-old; and Euphractus sexcinctus, Nasua nasua, Eira barbara and Puma concolor at 4-5 year-old stands. Two species occurred in all stand ages: Myrmecophaga tridactyla and Dasypus novemcinctus. All trophic categories, with the excep-
Tab. 2 - Species-incidence curve with Bootstrap procedure. ( $\left.r_{\mathrm{obs}}\right)$ : observed species richness; $\left(r_{\text {est }}\right)$ : estimated species richness; $\left(r_{\text {obs }} / r_{\text {est }} 100\right)$ : percentage of the estimated species richness actually detected.

\begin{tabular}{llccc}
\hline $\begin{array}{l}\text { Trophic } \\
\text { category }\end{array}$ & Stand age & $\boldsymbol{r}_{\text {obs }}$ & $\boldsymbol{r}_{\text {est }}$ & $\boldsymbol{r}_{\text {obs }} / \boldsymbol{r}_{\text {est }} \mathbf{1 0 0}(\mathbf{\%})$ \\
\hline Herbivores & $0-1$ & 3 & 3.6 & 83.4 \\
& $2-3$ & 3 & 3.7 & 81 \\
& $4-5$ & 2 & 2.3 & 87 \\
& $6-7$ & 1 & 1.3 & 77 \\
\hline Omnivores & Subtotal & 5 & 5.8 & 86.2 \\
& $0-1$ & 4 & 4.7 & 85 \\
& $2-3$ & 4 & 4.2 & 95.2 \\
& $4-5$ & 5 & 5.7 & 88 \\
& $6-7$ & 1 & 1.3 & 77 \\
\hline Insectivores & Subtotal & $6-1$ & 6.7 & 89.5 \\
& $2-3$ & 1 & 1.4 & 1 \\
& $4-5$ & 2 & 1 & 83.3 \\
& $6-7$ & 1 & 2.4 & 71.5 \\
& Subtotal & 2 & 1.4 & 83.3 \\
\hline Carnivores & $0-1$ & 1 & 2.4 & 71.5 \\
& $2-3$ & 0 & 1.4 & 0 \\
& $4-5$ & 1 & 0 & 0 \\
& $6-7$ & 0 & 1 & 80 \\
\hline Total & Subtotal & 2 & 0 & 82.1 \\
& $0-1$ & 9 & 2.5 & 90.6 \\
& $2-3$ & 8 & 11 & 87.7 \\
& $4-5$ & 10 & 8.9 & 85.9 \\
& $6-7$ & 3 & 4.4 & \\
\hline
\end{tabular}


Fig. 2 - Analysis of Means $(\alpha<0.05)$, according to Ott (1967) for species richness and frequency of occurrence for the whole species group and for omnivorous species by distinct Eucalyptus stand ages. 




Fig. 3 - Venn's Diagrams showing overlaps of species (A) and trophic categories (B) occurrence in Eucalyptus plantations of distinct ages. (Dn): Dasypus novemcinctus; (Es): Eupractus sexcinctus; (Mt): Myrmecophaga tridactyla; (Lsp): Lepus sp.; (Sb): Sylvilagus brasiliensis; (Pt): Pecari tajacu; (Msp): Mazama sp.; (Bt): Bos taurus; (Lp); Leopardus tigrinus; (Pc): Puma concolor; (Clf): Canis lupus familiaris; (Ct): Cerdocyon thous; (Cb): Chrysocyon brachyurus; (Eb): Eira barbara; (Nn): Nasua nasua; (Omn): Omnivores; (Carn): Carnivores; (Herb): Herbivores; (Inset): Insectivores.

tion of carnivores (absent in 2-3 and 6-7 year-old stands) occurred at all Eucalyptus stand ages (Fig. 3).

\section{Discussion}

The total species composition found in this study is similar to other studies carried out in the same region (Silveira 2005, Carvalho 2009, Alves et al. 2012). Although relatively small, the present sampling effort was sufficient to detect $86 \%$ of the total estimated number of species of middle to large-sized mammals that use local Eucalyptus plantations in central-south state of São Paulo, in south-eastern Brazil. However, methodological bias for terrestrial species possibly prevented the detection of primates (São Bernardo \& Galetti 2004), as well as the capybara (Hydrochoerus hydrochaeris - Verdade \& Ferraz 2006) and the Neotropical otter (Lontra longicaudis - Pardini 1998, Pardini \& Trajano 1999), respectively arboreal, semi-aquatic and aquatic species.

The manned-wolf (Chrysocyon brachyurus) and the crab-eating fox (Cerdocyon thous) were the most abundant species at the present study. Both species are omnivorous with generalist diet including plant matter, invertebrates and small vertebrates. Such a diet provides them with a wide feeding niche, allowing them to feed on different resources according to availability (Eisenberg \& Redford 2000). Armadillos (Dasypus spp.) and giant ant-eaters (Myrmecophaga tridactyla) were also abundant, possibly for eating insects (in particular ants and termites) usually abundant in Eucalyptus plantations (Breece \& Dusi 1985, Medri et al. 2003). As a matter of fact, ants are considered the most important "plague" of Eucalyptus plantations in southeastern Brazil, de- manding a rigorous control by the pulp and paper industry (Ramos et al. 2004). In addition to ants and termites, other opportunistic invertebrates and small vertebrate species can be found in Eucalyptus plantations possibly due to its relatively fast growth (i.e., biomass production - Benton et al. 2003, Pawson et al. 2009, Meers et al. 2010). These species are possibly food resources for middle to large-sized mammals (Crooks \& Soulé 1999, Sullivan et al. 2007).

Herbivores, in especial the European hare (Lepus spp.) are relatively abundant in the early stages of Eucalyptus plantations (0-1 year), possibly favored by the abundance of remaining grass still present as the former landscape matrix was formed by exotic pasture land (predominantly Brachyarya $=$ Urochloa spp.). However, later (2-5 years), omnivores and insectivores become more numerous possibly because of the presence of some understory vegetation used by arthropods and small vertebrates. However, in the final stage of commercial Eucalyptus stands (6-7 years) all trophic categories drastically decrease in number of species and frequency of occurrence. At this stage mechanical trimmings become more frequent, resulting in the removal of the understory vegetation in order to facilitate harvest (de Moraes Goncalves et al. 2004, Wagner et al. 2006). Such intense weed control is usually overdone in order to avoid legal problems with local environmental agencies as even an economically viable understory vegetation can be considered as native revegetation that requires especial license to be cut (see Lei No. 11.428, from $22^{\text {nd }}$ December 2006; Resolução CONAMA No. 338, from 23 February 2007; Resolução CONAMA No. 392, from 25 June 2007; Portaria DEPRN No.
08, from 20 November 1989 and Decreto Estadual 53.027-2008). Such management practice seems rather ineffective for both the pulp and paper industry and the environmental quality as the maintenance of some understory vegetation is undoubtedly better for the wildlife than no vegetation at all. In addition, a less intense weed control could result in cost reduction for the pulp and paper industry and its consumers.

\section{Conclusions}

The detected temporal variation in the use of Eucalyptus stands by middle to largesized mammals is possibly related to the relatively high temporal heterogeneity of this environment as well as to the silvicultural practices along its commercial cycle (Fischer \& Lindenmayer 2006). According to the "continuum model" (Manning et al. 2004, Farina \& Belgrano 2006, Fischer \& Lindenmayer 2006, Lindenmayer \& Fischer 2007) animal species are distributed as a continuum in the landscape, spatially and temporally, according to the distribution of resources in a pattern that resembles a dégradé more than on a well-defined patchwork pattern. In such model, species will move, use, and therefore, occur on a determined environment at a certain moment depending on its resources availability and the species' ability to access them (Manning et al. 2004). The present species are relatively common in silvicultural landscapes. However, their use of resources associated with the landscape matrix (i.e., Eucalyptus plantations themselves) are directly associated to the silvicultural practices along commercial plantation cycles. Such principle should be considered by the certification process of the pulp and paper industry (FSC 2013) in order to pro- 
mote and maintain a sustainable conservation value for silvicultural landscapes in south-eastern Brazil.

\section{Acknowlegdements}

We would like to thank Júlio César Costa, Gustavo Sigrist Betini, Sabrina KoesterGobbo and other colleagues for the assistance in the field. This study received financial support from FAPESP (Proc. No 2006/60954-4), CNPq (Proc. No. 142732/ 2007-9) and Eucatex S/A. LMV has a productive research fellowship from CNPq.

\section{References}

ABRAF (2013). Anuário estatístico ABRAF 2013 ano base 2012 [Statistical Annuary ABRAF 2013 base year 2012]. ABRAF, Brasília, Brazil, pp. 148. [in Portuguese]

Acharya K (2006). Linking trees on farms with biodiversity conservation in subsistence farming systems in Nepal. Biodiversity and Conservation 15: 631-646. - doi: 10.1007/s10531-005-2091-7 Alves TR, Fonseca RCB, Engel VL (2012). Mamíferos de médio e grande porte e sua relação com o mosaico de habitats na cuesta de Botucatu, Estado de São Paulo, Brasil [Medium and large sized mammalians and their relation to habitat patches at the Botucatu cuesta, state of São Paulo, Brazil]. Iheringia. Série Zoologia 102: 150-158. [in Portuguese] - doi: 10.1590/S0 073-47212012000200006

Benton TG, Vickery JA, Wilson JD (2003). Farmland biodiversity: is habitat heterogeneity the key? Trends in Ecology and Evolution 18: 182188. - doi: 10.1016/S0169-5347(03)00011-9

Breece GA, Dusi JL (1985). Food habitats and home range of the common long-nosed armadillo Dasypus novemcinctus in Alabama. In: "The evolution and ecology of armadillos, sloths and vermilinguas" (Montgomery GG ed). Smithsonian Institution Press, Washington, USA, pp 419-427.

Carvalho FC (2009). Levantamento da mastofauna terrestre de médio e grande porte em remanescente de floresta neotropical - Itatinga, SP [Terrestrial medium to large-sized mammal fauna assessment in a neotropical forest fragment - Itatinga, SP]. Graduation Monography, Instituto de Biociências de Botucatu, Universidade Estadual Paulista "Júlio de Mesquita Filho", Botucatu, SP, Brazil, pp. 18. [in Portuguese]

CEPAGRI-UNICAMP (2012). Clima dos municípios paulistas. Web site. [in Portuguese] [online] URL: http://www.cpa.unicamp.br/outras-informacoes/clima-dos-municipios-paulistas.html

Colwell RK, Mao CX, Chang J (2004). Interpolating, extrapolating, and comparing incidencebased species accumulation curves. Ecology 85: 2717-2727. - doi: 10.1890/03-0557

Crooks KR, Soulé ME (1999). Mesopredator release and avifaunal extinctions in a fragmented system. Nature 400: 563-566. - doi: 10.1038/ 23028

de Moraes Goncalves JL, Stape JL, Laclau JP, Smethurst P, Gava JL (2004). Silvicultural ef- fects on the productivity and wood quality of eucalypt plantations. Forest Ecology and Management 193: 45-61. - doi: 10.1016/j.foreco.2004. 01.022

Dotta G (2005). Diversidade de mamíferos de médio e grande porte em relação à paisagem da bacia do rio Passa-Cinco, São Paulo [Diversity of medium and large-sized mammals in relation to the landscape atributes in the Passa-Cinco river basin, São Paulo]. Master Degree Dissertation, Universidade de São Paulo, Piracicaba, SP, Brazil, pp. 116. [in Portuguese]

Dotta G, Verdade LM (2007). Trophic categories in a mammal assemblage: diversity in an agricultural landscape. Biota Neotropica 7: 287-292. doi: 10.1590/S1676-06032007000200031

Dotta G, Verdade LM (2011). Medium to largesized mammals in agricultural landscapes of South-Eastern Brazil. Mammalia 75: 345.

Eisenberg JF, Redford KH (2000). Mammals of the neotropics, vol. 3: Ecuador, Bolivia, Brazil. University of Chicago Press, IL, USA, pp. 624.

Fahrig L (2003). Effects of habitat fragmentation on biodiversity. Annual Review of Ecology, Evolution, and Systematics 34: 487-515. - doi: 10.1146/annurev.ecolsys.34.011802.132419

Faria D, Laps R, Baumgarten J, Cetra M (2006). Bat and bird assemblages from forests and shade cacao plantations in two contrasting landscapes in the Atlantic Forest of Southern Bahia, Brazil. Biodiversity and Conservation 15: 587-612. doi: 10.1007/s10531-005-2089-1

Farina A, Belgrano A (2006). The eco-field hypothesis: toward a cognitive landscape. Landscape Ecology 21: 5-17. - doi: 10.1007/s10980005-7755-X

Farnum NR, Stanton LW (1989). Quantitative forecasting methods. PWS Publishers, Boston, MS, USA, pp. 656.

Fischer J, Lindenmayer DB (2006). Beyond fragmentation: the continuum model for fauna research and conservation in human-modified landscapes. Oikos 112: 473-480. - doi: 10.1111/ j.0030-1299.2006.14148.x

Fonseca GAB, Herrmann G, Leite YLR, Meittermeier RA, Rylands AB, Patton JL (1996). Lista anotada dos mamíferos do Brasil [Annotated checklist of Brazilian mammals]. Conservation International, Washington, USA, pp. 38. [in Portuguese]

FSC (2013). Global FSC certificates: type and distribution. Web site. [in Portuguese] [online] URL: http://br.fsc.org/fatos-e-nmeros.188.htm

Goodwin BJ, Fahrig L (2002). How does landscape structure influence landscape connectivity? Oikos 99: 552-570. - doi: 10.1034/j.16000706.2002.11824.x

Harvey C, González Villalobos J (2007). Agroforestry systems conserve species-rich but modified assemblages of tropical birds and bats. Biodiversity and Conservation 16: 2257-2292. - doi: 10.1007/s10531-007-9194-2

Harvey CA, Medina A, Sánchez DM, Vílchez S, Hernández B, Saenz JC, Maes JM, Casanoves F, Sinclair FL (2006). Patterns of animal diversity in different forms of tree cover in agricultural landscapes. Ecological Applications 16: 19861999. - doi: 10.1890/1051-0761(2006)016[1986: POADID]2.0.CO;2

Hector A, von Felten S, Schmid B (2010). Analysis of variance with unbalanced data: an update for ecology and evolution. Journal of Animal Ecology 79: 308-316. - doi: 10.1111/j.13652656.2009.01634.x

Karanth KU, Nichols JD, Kumar NS (2004). Photographic sampling of elusive mammals in tropical forests. In: "Sampling rare or elusive species: Concepts, designs, and techniques for estimating population parameters" (Thompson WL, Burnham KP eds). Island Press, Washington, DC, USA, pp. 229-247.

Kays RW, Slauson KM (2008). Remote cameras. In: "Noninvasive survey methods for carnivores" (Long RA, MacKay P, Ray J, Zielinski W eds). Island Press, Washington, DC, USA, pp. 110140

Kronka JN, Nalon MA, Matsukuma CK, Pavão M, Ywane MSS, Kanashiro MM, Lima LMPR, Pires AS, Shid CN, Fukuda JC, Guillaumon JR (2002). Inventário florestal das áreas reflorestadas no Estado de São Paulo [Forest inventory of reforested areas in State of São Paulo]. Secreteraia do Meio Ambiente, Instituto Florestal, São Paulo, Brazil, pp. 184. [in Portuguese] Levene H (1960). Robust test for equality of variances. In: "Contributions to probability and statistics: Essays in honor of Harold Hotelling" (Olkin I ed). Stanford University Press, Stanford, CA, USA, pp. 278-292.

Lilliefors HW (1967). On the Kolmogorov-Smirnov test for normality with mean and variance unknown. Journal of the American Statistical Association 62: 399-402. - doi: 10.1080/0162 1459.1967.10482916

Lindenmayer DB, Fischer J (2007). Tackling the habitat fragmentation panchreston. Trends in Ecology and Evolution 22: 127-132. - doi: 10.1016/j.tree.2006.11.006

Lyra-Jorge M, Ciocheti G, Pivello V (2008). Carnivore mammals in a fragmented landscape in Northeast of São Paulo state, Brazil. Biodiversity and Conservation 17: 1573-1580. - doi: 10.1007/ s10531-008-9366-8

Manning AD, Lindenmayer DB, Nix HA (2004). Continua and umwelt: novel perspectives on viewing landscapes. Oikos 104: 621-628. - doi: 10.1111/j.0030-1299.2004.12813.x

Martin PS, Gheler-Costa C, Lopes PC, Rosalino LM, Verdade LM (2012). Terrestrial non-volant small mammals in agro-silvicultural landscapes of Southeastern Brazil. Forest Ecology and Management 282: 185-195. - doi: 10.1016/j.foreco. 2012.07.002

Medri IM, Mourão GM, Harada AY (2003). Dieta de tamanduá-bandeira (Myrmecophaga tridactyla) no Pantanal da Nhecol'ndia, Brasil [Diet of giant-anteater (Myrmecophaga tridactyla) at Nhecolândia Pantanal, Brazil]. Edentata 5: 29-34. [in Portuguese with English abstract] [online] URL: http://www.asasg.org/resources/bibliography/70Edentata $\% 205$.pdf\#page $=31$ 
Meers TL, Kasel S, Bell TL, Enright NJ (2010). Conversion of native forest to exotic Pinus radiata plantation: Response of understorey plant composition using a plant functional trait approach. Forest Ecology and Management 259: 399-409. - doi: 10.1016/j.foreco.2009.10.035

Moffett MW (2000). What's "up"? A critical look at the basic terms of canopy biology. Biotropica 32: 569-596. - doi: 10.1646/0006-3606(2000) 032[0569:WSUACL]2.0.CO;2

Moguel P, Toledo VM (1999). Biodiversity conservation in traditional coffee systems of Mexico. Conservation Biology 13: 11-21. - doi: 10.10 46/j.1523-1739.1999.97153.x

Moktefi A, Shin S-J (2012). A history of logic diagrams. In: "Handbook of the history of logic" (Gabbay DM, Pelletier FJ, Woods J eds). NorthHolland, Elsevier, pp. 611-682. - doi: 10.1016/ B978-0-444-52937-4.50011-3

Ott ER (1967). Analysis of means - a graphical procedure. Industrial Quality Control 24: 101109

Pardini R (1998). Feeding ecology of the neotropical river otter Lontra longicaudis in an Atlantic Forest stream, South-Eastern Brazil. Journal of Zoology 245: 385-391. - doi: 10.1111/j.14697998.1998.tb00113.x

Pardini R, Ditt EH, Cullen L Jr, Bassi C, Rudran $R$ (2003). Levantamento rápido de mamíferos terrestres de médio e grande porte [Rapid assessment of medium to large-sized terrestrial mammals]. In: "Métodos de estudos em biologia da conservação e manejo da vida silvestre" (Cullen L Jr, Rudran R, Valladares-Padua C eds). UFPR, Fundação $\mathrm{O}$ Boticário de Proteção à Natureza, Curitiba, Brazil, pp. 181-201. [in Portuguese]

Pardini R, Trajano E (1999). Use of shelters by the neotropical river otter (Lontra longicaudis) in an Atlantic Forest stream, Southeastern Brazil. Journal of Mammalogy 80: 600-610. - doi: 10.23 07/1383304

Parker GG, Brown MJ (2000). Forest canopy stratification - is it useful? American Naturalis 155: 473-484. - doi: 10.1086/303340

Pawson SM, Brockerhoff EG, Didham RK (2009). Native forest generalists dominate carabid assemblages along a stand age chronosequence in an exotic Pinus radiata plantation. Forest Ecology and Management 258: S108-S116. - doi: 10.1016/j.foreco.2009.08.012

Penteado M (2006). Distribuição e abund'ncia de aves em relação ao uso da terra na bacia do rio Passa-Cinco, Estado de São Paulo, Brasil [Distribution and abundance of birds in relation to land use in Passa-Cinco river basin, state of São Paulo, Brazil]. PhD Thesis, Universidade de São Paulo, Piracicaba, SP, Brazil, pp. 131. [in Portuguese]

Ramos L, Zanetti R, Marinho CGS, Delabie JHC, Schlindwein MN, Almado R (2004). Impacto das capinas mec'nica e química do sub-bosque de Eucalyptus grandis sobre a comunidade de formigas (Hymenoptera: Formicidae) [Impact of mechanical and chemical weedings of Eucalyptus grandis undergrowth on an ant community (Hymenoptera: Formicidae)]. Revista Árvore 28: 139-146. [in Portuguese]

Ray J, Zielinski W (2008). Track stations. In: "Noninvasive survey methods for carnivores" (Long RA, MacKay P, Ray J, Zielinski W eds). Island Press, Washington, DC, USA, pp. 75-109. Robinson JG, Redford KH (1986a). Body size, diet, and population density of neotropical forest mammals. American Naturalist 128: 665. [online] URL: http://www.jstor.org/stable/2461950 Robinson JG, Redford KH (1986b). Intrinsic rate of natural increase in neotropical forest mammals - relationship to phylogeny and diet. Oecologia 68: 516-520. - doi: 10.1007/BF00378765

São Bernardo CS, Galetti M (2004). Densidade e tamanho populacional de primatas em um fragmento florestal no Sudeste do Brasil [Density and population size of primates in a forest fragment in southeastern Brazil]. Revista Brasileira de Zoologia 21: 827-832. [in Portuguese] - doi: 10.1590/S0101-81752004000400017

Silveira PB (2005). Mamíferos de médio e grande porte em florestas de Eucaliptus spp. com diferentes densidades de sub-bosque no município de Itatinga, sp. [Medium and large-sized mammals in forests of Eucalyptus spp. with different densities of understories in Itatinga, state of São Paulo, Brazil]. Master Degree Dissertation, Ciências Florestais, USP, Piracicaba, SP, Brazil, pp. 75. [in Portuguese]

Smith EP, van Belle G (1984). Nonparametric estimation of species richness. Biometrics 40: 119129. - doi: $10.2307 / 2530750$

Sullivan TP, Sullivan DS, Lindgren PMF, Ransome DB (2007). Long-term responses of ecosystem components to stand thinning in young lodgepole pine forest IV. Relative habitat use by mammalian herbivores. Forest Ecology and Management 240: 32-41. - doi: 10.1016/j.foreco. 2006.11.020

Tilman D, Fargione J, Wolff B, Antonio C, Dobson A, Howarth R, Schindler D, Schlesinger
WH, Simberloff D, Swackhamer D (2001). Forecasting agriculturally driven global environmental change. Science 292: 281-284. - doi: 10.11 26/science. 1057544

Turnbull JW (1995). Eucalypt plantations. In: Proceedings of the Symposium "On the Variety, Types and Significance of Planted Forests Technical and Social Considerations for Planted Forests". Portland (Oregon, USA) Jun 28 - Jul 1 1995. Kluwer Academic Publisher, Portland, OR, USA, pp. 37-52.

Veloso HP (1992). Phytogeographical system. In: "Manual técnico da vegetação brasileira" (Secretaria de Planejamento OeC, Fundação Instituto Brasileiro de Geografia e Estatística, IBGE, Diretoria de Geociências, Departamento de Recursos Naturais e Estudos Ambientais eds). IBGE, Rio de Janeiro, Brazil, pp. 9-38. [in Portuguese] Verdade LM, Ferraz KM (2006). Capybaras in an anthropogenic habitat in Southeastern Brazil. Brazilian Journal of Biology 66 (1b): 371-378 . doi: 10.1590/S1519-69842006000200019

Verdade LM, Gheler-Costa C, Penteado M, Dotta G (2012). The impacts of sugarcane expansion on wildlife in the State of São Paulo, Brazil. Journal of Sustainable Bioenergy Systems 2: 138-144. - doi: 10.4236/jsbs.2012.24020

Verdade LM, Rosalino LM, Gheler-Costa C, Pedroso NM, Lyra-Jorge MC (2011). Adaptation of mesocarnivores (mammalia: Carnivora) to agricultural landscapes in Mediterranean Europe and Southeastern Brazil: a trophic perspective. In: "Middle-sized carnivores in agricultural landscapes" (Rosalino LM, Gheler-Costa C eds). Nova Science Publishers, New York, USA, pp. $1-38$

Wagner RG, Little KM, Richardson B, McNabb K (2006). The role of vegetation management for enhancing productivity of the world's forests. Forestry 79: 57-79. - doi: 10.1093/forestry/cpi 057

Wemmer C, Kunz TH, Lundie-Jenkins G, McShea WJ (1996). Mammalian sign. In: "Measuring and monitoring biogical diversity: Standard methods for mammals" (Wilson DE, Cole FR, Nichols JD, Rudran R, Foster MS eds). Smithsonian Institution, Washington, DC, USA, pp. 157 176

Wilson DE, Reeder DM (2005). Mammal species of the world: a taxonomic and geographic reference. Johns Hopkins University Press, Baltimore, MD, USA, vol. 2, pp. 2142. 